\title{
Ultrastructural observations on sporozoite stages of piscine Coccidia: Goussia carpelli and G. subepithelialis from the intestine of tubificid oligochaetes
}

\author{
Dieter Steinhagen
}

Fish Disease Research Unit, School of Veterinary Medicine, Bünteweg 17, W-3000 Hannover 71, Germany

\begin{abstract}
Sporozoites of the piscine coccidians Goussia carpelli and G. subepithelialis excysted from sporocysts when ingested by tubificid oligochaetes Tubifex tubifex and Limnodrilus hoffmeisteri, and invaded cells of the alimentary tract. There the sporozoites were found singly in membrane-bound parasitophorous vacuoles and persisted for $9 \mathrm{wk}$ for $G$. carpelli and $3 \mathrm{wk}$ for $G$. subepithelialis. The fine structure of the sporozoites agreed with ultrastructural details known from other eimerian type sporozoites. The cells possessed e.g. refractile bodies, micronemes and dense granules, and were limited by a 3-layered pellicle. G. carpelli sporozoites, which were studied in more detail, showed no alteration in ultrastructure during 9 wk of observation and remained infective for carp.
\end{abstract}

\section{INTRODUCTION}

Goussia carpelli (Léger \& Stankovitch, 1921) and Goussia subepithelialis (Moroff \& Fiebiger, 1905) are gut-dwelling coccidian parasites of common carp $C y$ prinus carpio L. which have often been reported to cause serious disease in hatchery populations of carp: 'enteritis coccidiosis' (G. carpelli) and 'nodular coccidiosis' (G. subepithelialis). The life cycles of these parasites were studied by Marincek (1973), who successfully infected carp in the laboratory with $G$. subepithelialis by oral inoculation of oocysts, and by Steinhagen \& Körting $(1988,1990)$, who laboratoryinfected carp with G. carpelli. Transmission of G. carpelli occurred directly by oral ingestion of oocysts but also by feeding carp on infected tubificids which were able to act as paratenic hosts.

The present communication reports data on the ultrastructure of Goussia carpelli and G. subepithelialis sporozoites found in intestinal cells of laboratoryinfected tubificids.

\section{MATERIALS AND METHODS}

Oligochaetes. Tubificid oligochaetes Tubifex tubifex and Limnodrilus hoffmeisteri were obtained from a laboratory stock kept in plastic tanks with a bottom layer of sterilized washed sand and filled with aerated tap water at room temperature. The worms were fed on pelleted dry fish food twice a week.

Coccidia. Goussia carpelli were isolated from common carp infected in the laboratory as described previously (Steinhagen \& Körting 1988). G. subepithelialis were isolated in March 1990 from 1 yr old carp obtained from the ponds of a hatchery near Celle, Lower Saxony, Germany.

Iniection experiments. Tubifex tubifex and Limnodrilus hoffmeisteri were fed on intestinal tissue and mucosal scrapings of carp containing sporulated coccidian oocysts, as described by Steinhagen \& Körting (1990).

Three days, 3 and 9 wk post exposure (PE), tubificids fed on Goussia carpelli were placed in $2.5 \%$ glutaraldehyde in $0.1 \mathrm{M}$ cacodylate buffer supplemented with $0.02 \% \mathrm{CaCl}_{2}$ at room temperature, then cut into small pieces and fixed in the same solution overnight at $4{ }^{\circ} \mathrm{C}$, postfixed in $1 \% \mathrm{OsO}_{4}$ in the same buffer for $1 \mathrm{~h}$, en bloc stained with $1 \%$ aquaeous uranyl acetate, dehydrated in a series of graded ethanol and embedded in Spurr's resin. To examine the infectivity of $G$. carpelli for carp, tubificids were fed at the same time to parasite-free carp as described previously (Steinhagen \& Körting 1990). 


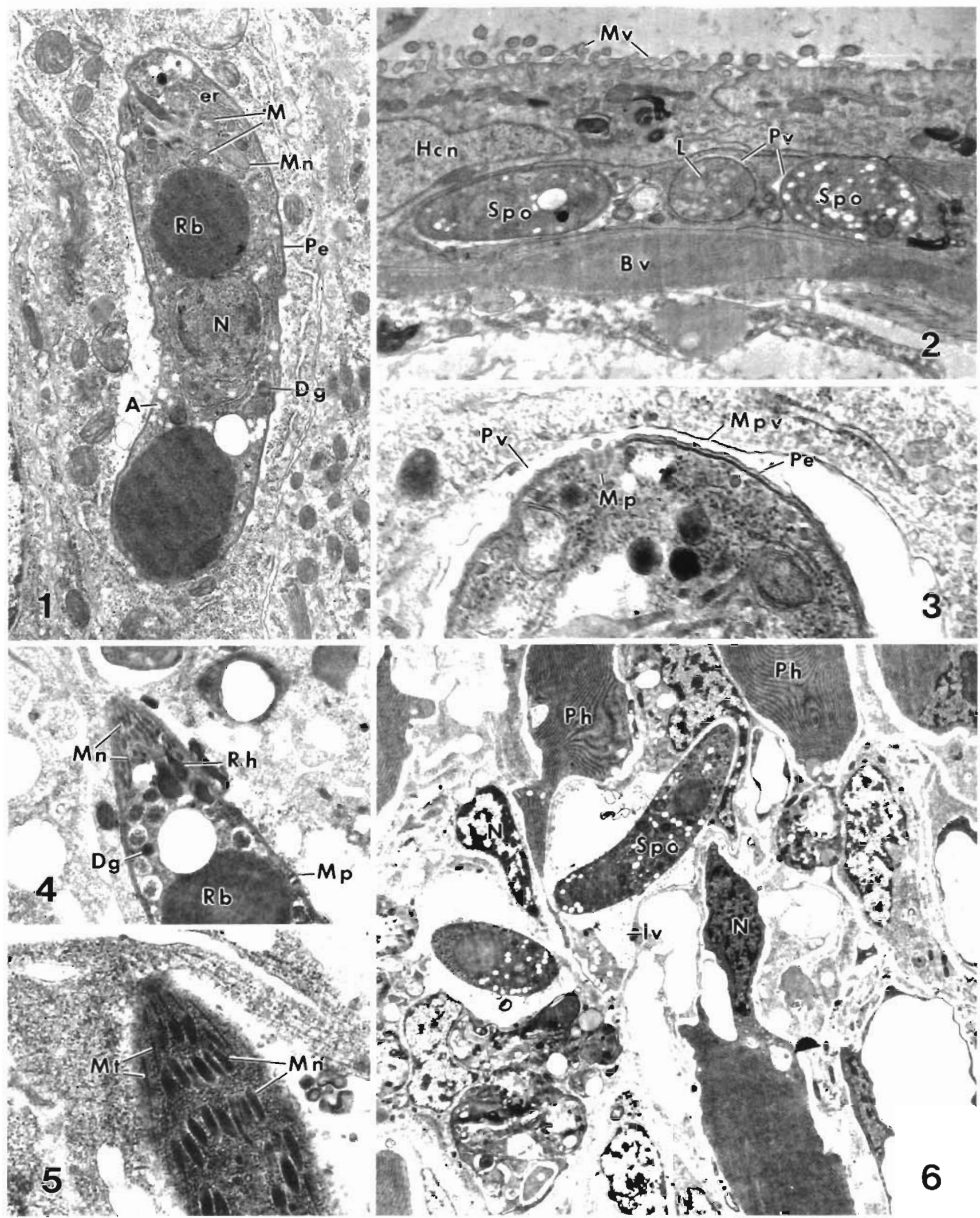

Figs 1 to 6 Goussıa carpell sporozoltes in Tubıtex tubifex. Fig 1. Sporozolte with 2 refractile bodies (Rb), central nucleus (N), mitochondra (M), micronemes (Mn), endoplasmic reticulum (er), dense granules (Dg), amylopectin inclusions (A), and limited by a 3-layered pellicle $(\mathrm{Pe})_{i} \times 13$ 600. Fig 2 Sporozoltes (Spo) withın membrane-bound parasitophorous vacuoles (Pv) in intestinal cells, located near blood vessels (Bv); Hcn. host cell nucleus. Mv microvilli of intestinal epithelial cells; L: lipid inclusions; $\times 13600$. Fig 3. Cross-section of sporozoite with 3-layered pellicle (Pe) and micropore (Mp) within a membrane-bound parasitophorous vacuole (Pv); Mpv membrane of the parasitophorous vacuole $\times 44100$. Fig. 4. Apical portion of a sporozoite whth rhoptries $(\mathrm{Rh})$ and penodically arranged micronemes $(\mathrm{Mn})$, pellıcle with a micropore $(\mathrm{Mp}) ; \times 15$ 000. Fig. 5. Superficial section of the apical region of a sporozotte showing micronemes and subpellicular microtubules (Mt); $\times 23500$. Fig. 6. Sporozoites 
Tubificids fed Goussia subepithehalss were examined in wet mounts at 6 and $24 \mathrm{~h}, 2,5,7,9$, and $13 \mathrm{~d}$, and 3 wk PE for the presence of coccidian stages For ultrastructural observations infected tubificids were fixed and embedded 3 wk PE as described above. Thin sections were cut with glass knives, stained with uranyl acetate and lead citrate and examined in a Zeiss EM 10 A electron microscope.

\section{RESULTS}

Goussia carpelli: Sporozoites were found singly in cells of the intestinal epithelium of infected tubificids in all samples taken during the observation interval (Figs. $1 \& 2$ ). The sporozoites were limited by a 3-layered pellicle with micropores (Fig. 3), possessed 2 prominent refractile bodies (Fig. 1), a central nucleus, mitochondria, lipid and amylopectin inclusions, electron-dense bodies, rhoptries (Figs. 1 to 4), and numerous micronemes which in the apical region of the cell appeared to be arranged in regular rows (Figs. $4 \& 5$ ). Beneath the pellicular complex subpellicular microtubules were found (Fig. 5), and on appropriate cross-sections 24 microtubules were counted (not shown). The sporozoites were incorporated in membrane-bound parasitophorous vacuoles (Fig. 3) often located in basal regions of the intestinal epithelium near blood vessels (Fig. 2). In the parasitophorous vacuole granular material could be discerned which appeared to accumulate during the infection (Fig. 6). In the host cell alterations were not obvious, but in the vicinity of infected cells with extended finger-print-like endoplasmic reticulum (ER) were observed (Fig 6).

During the observation period Goussia carpelli sporozoites in tubificids remained infective for carp.

Goussia subepithelialis: Sporocysts and motile sporozoites were found in wet mounts of tublficids fed on intestinal material from carp infected with G. subepithelialis. At 6 and $24 \mathrm{~h}$ PE mainly oocysts were present and single sporozoites occurred, but later samples contained only motile sporozoites measuring $3 \times 13 \mu \mathrm{m}$. In tissue sections $G$. subepthelialis sporozoites were present in epithelial and phagocytic cells of the alimentary canal within a parasitophorous vacuole which often contained granular matenal (Fig. 7). The sporozoites exhibited ultrastructural features of coccidian sporozoites as described above, with refractile bodies, a central nucleus, amylopectin inclusions, dense bodies, numerous micronemes, 2 apical polar rings (Figs. $7 \& 8$ ) and 28 subpellicular microtubules (not shown). Sporozoites often were found in cells with extended ER (Fig. 8), numerous ribosomes and phagocytic vacuoles and often the sporozoite pellicle showed signs of destruction.

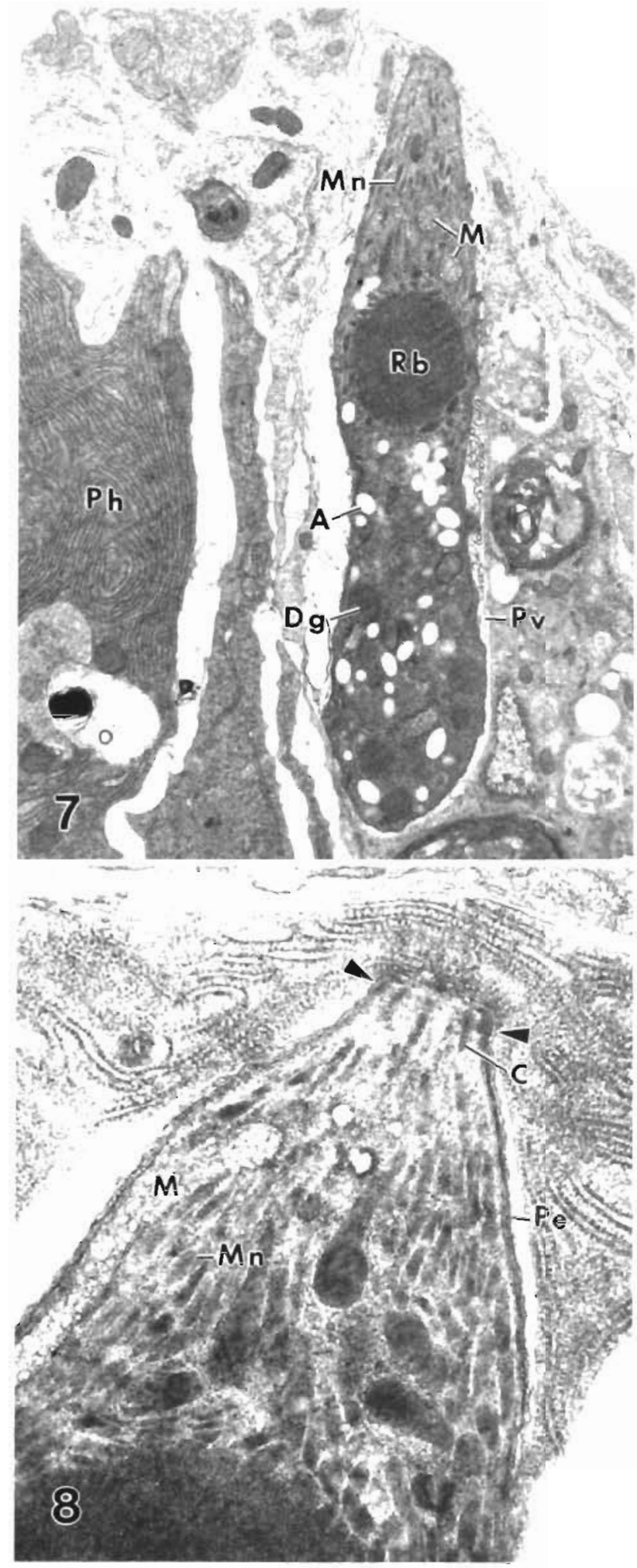

Figs. 7 \& 8 . Goussia subepithellahs sporozoites in Tubıfex tubifex. Fig 7. Sporozolte, general ultrastructural features Abbreviations as in Fig. 1; $\times 12600$ Fig. 8. Apical part of the sporozoite with conold (C) and polar nngs (arrows); $\times 28300$ 
Attempts to experimentally infect carp with G. subepithelialis by feeding carp on infected tubificids are in progress.

\section{DISCUSSION}

Results show that Goussia carpelli sporozoites may invade intestinal cells of tubificids and survive for several weeks. These parasitized tubificids have been shown to transmit $G$. carpelli to carp (Steinhagen \& Körting 1990, this study). In the tubificids, the sporozoites did not undergo any further steps of development nor were any signs of degeneration observed. The invertebrate host did not develop any cystic envelope, but during the observation time the sporozoites persisted in the intestinai tissue, often in the vicinity of blood vessels. Sporozoites of piscine coccidia have also been found in cells of the hepatopancreas of shrimps (Calyptospora funduli; Fournie \& Overstreet 1983) and within intestinal cells of mysidian shrimps (Eimeria sp. from the intestine of a moray eel Gymnothorax moringa; Landau et al. 1975), but ultrastructural observations on these stages were not reported. The fine structure of coccidian sporozoites from paratenic hosts, however, was described in extraintestinal infections of mice with an Isospora species from dogs (Dubey \& Mehlhorn 1978). After feeding mice on $I$. ohioensis oocysts, sporozoites were found singly within parasitophorous vacuoles in cells of various organs. Besides an increase in size the parasites did not change ultrastructural characters during the observation period and remained infective to dogs; these stages were therefore regarded as sporozoites in diapause (Dubey \& Mehlhorn 1978, Fayer \& Reid 1982). Paperna \& Ostrovska (1989) found similar sporozoite stages in hepatocytes and macrophages of Agama stellio infected with Schellackia cf. agamae.

The ultrastructure of Goussia carpelli sporozoites from the intestinal tissue of tubificids agrees in most fine structural details with other known sporozoites of piscine coccidia (e.g. Paterson \& Desser 1984, Morrison \& Poynton 1989) and conforms to the ultrastructural model of eimerian coccidian sporozoites (Scholtyseck 1979, Chobotar \& Scholtyseck 1982). Compared to $G$. carpelli sporozoites not yet released from sporocysts (Lom \& Steinhagen unpubl.), no differences in fine structural details were obvious in those sporozoites observed in tubificid intestinal tissue, and during the observation period of 9 wk PE no alteration of ultrastructural features of the sporozoites were seen.

Sporozoites of Goussia subepithelialis excysted from the sporocyst shells after ingestion by tubificids and like $G$. carpelli sporozoites then invaded cells of the alimentary canal where they were found singly in a membrane-bound parasitophorous vacuole. The ultrastructural features of these sporozoites also showed no differences to those not yet released from sporocysts (unpubl. obs.). But unlike G. carpelli, G, subepithelialis sporozoites were mainly found in phagocytic cells, and in the samples numerous degenerating stages were observed. Regarding the information available at present, the role of tubificids in the life cycle of $G$. subepithelialis could not be decided. Marincek (1973) successfully infected carp with $G$. subepithelialis in the laboratory by oral inoculation of oocysts. The excystation of $G$. subepithelialis sporozoites from sporocysts ingested by tubificids (this study), however, suggests that these oligochaetes also might be involved in the transmission of this parasite. The ability of gut-dwelling piscine coccidia to infect hosts elther directly by oral uptake of oocysts from the environment or by feeding on invertebrate paratenic hosts was discussed by Desser (1981) and later was demonstrated for $G$. carpelli (cf. Steinhagen \& Körting 1990).

Acknowledgements. Prof. Dr W. B. van Muiswinkel and Mr S. H. Leenstra, Agricultural University, Wageningen, The Netherlands, kindly provided parasite-free carp eggs. Ultrastructural observations were performed using the equipment of the Electron Microscopy Working Group, Botany Department, School of Veterinary Medicine, Hannover. This study was supported by DFG grant Ste 420/1-1,1-2.

\section{LITERATURE CITED}

Chobotar, B., Scholtyseck, E. (1982). Ultrastructure. In: Long, P. L. (ed.) The biology of the Coccidia. Edward Arnold Press, London, p. 101-165

Desser, S. S. (1981). The challenge of fish coccidia. J. Protozool. 28: 260-261

Dubey, J. P., Mehlhorn, H. (1978). Extraintestinal stages of Isospora ohioensis from dogs in mice. J. Parasitol. 64: 689-695

Fayer, R., Reid, W. M. (1982). Control of coccidiosis. In: Long, P. L. (ed.) The biology of the Coccidia. Edward Amold Press, London, p. 453-487

Fournie, J. W., Overstreet, R. M. (1983). True intermediate hosts for Eimeria funduli (Apicomplexa) from estuarine fishes. J. Protozool. 30: 672-675

Landau, I., Marteau, M., Golvan, Y., Chaband, A. G., Boulard, $Y$ (1975). Hétéroxénie chez les coccidies intestinales de poissons. C. r. Acad. Sci., Paris, Series D 281: 1721-1723

Marincek, M. (1973). Developpment d'Eimeria subepithelialis (Sporozoa, Coccidia) - parasite de la carpe. Acta Parasitol. 12: $195-215$

Morrison, C. M., Poynton, S. L. (1989). A new species of Goussia (Apicomplexa, Coccidia) in the kidney of the cod, Gadus morhua. J. Fish Dis. 12: 533-560

Paperna, I., Ostrovska, K. (1989). Ultrastructural studies on sporozoite stages of Schellackia cf. agamae from liver and blood of the starred lizard Agama stellio. Int. J. Parasitol. 19: $13-19$

Paterson, W. B., Desser, S. S. (1984). Ultrastructural observations on fertilization and sporulation in Goussia iroquoina 
(Molnar and Fernando, 1974) in experimentally infected fathead minnows (Pimephales promelas, Cyprinidae). $J$ Parasitol. 70: 703-711

Scholtyseck, E. (1979). Fine structure of parasitic protozoa Springer, Berlin

Steinhagen, D., Körting, W. (1988). Experimental transmission

Editiorial sesponsibility: Managing Editor of Coussia carpelli (Léger \& Stankovitch, 1921) (Protista: Apicomplexal to common carp. Cyprinus carpio L. Bull. Eur. Ass. Fish Path. 8: 112-113

Steinhagen, D. Körting, W. (1990). The role of tubificid oligochaetes in the transmission of Goussia carpelli. J. Parasitol. 76: 104-107

Manuscript first received: November 5, 1990 Revised version accepted: January 15, 1991 